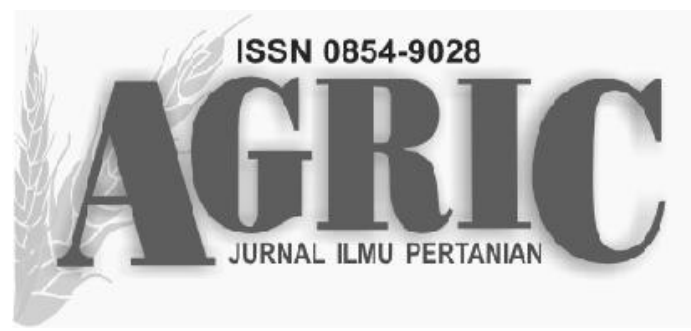

Fakultas Pertanian dan Bisnis Universitas Kristen Satya Wacana JI. Diponegoro 52-60 SALATIGA 50711 - Telp. 0298-321212 ext 354 email: agric_fpb@yahoo.co.id, website: ejournal.uksw.edu/agric

\title{
EKSTRAKSI BETASIANIN DARI KULIT UMBI BIT(Beta vulgaris) SEBAGAI PEWARNA ALAMI
}

\section{EXTRACTION OF BETACYANIN FROM BEET (Beta vulgaris) PEEL FOR NATURAL DYES}

\author{
Martinus Andree Wijaya Setiawan \\ Magister Agroekoteknologi Fakultas Pertanian dan Bisnis, Universitas Kristen Satya Wacana \\ J1. Diponegoro 52-60 Salatiga \\ Erik Kado Nugroho \\ Magister Agroekoteknologi Fakultas Pertanian dan Bisnis, Universitas Kristen Satya Wacana \\ Jl. Diponegoro 52-60 Salatiga \\ erikkado@gmail.com \\ Lydia Ninan Lestario \\ Program Studi Kimia Fakultas Sains dan Matematika, Universitas Kristen Satya Wacana \\ J1. Diponegoro 52-60 Salatiga \\ lydia.ninan@staff.uksw.edu
}

Diterima 20 April 2015, disetujui 1 Juni 2015

\begin{abstract}
The aim of this research was to know most effective solvent comparison (ethanol, ethanol:HCL, ethanol: Citric Acid) on the betacyanin extract properties from Beet Peel. The characteristic of Beet Peel contain 82,85 percent water, fiber 5,95 percent, ash 1,33 percent, and lipid 0,31 percent. The research was also aimed to know potential of Beet Peel for narutal dyes. This research was conducted only to compare effectivity of three different solvent that use to extract Beet Peel, temperature that use for extraction are the same at $30^{\circ} \mathrm{C}$ for 40 minute. The best characteristic of extract was obtained from the ethanol: $\mathrm{HCL}$ with betalain of 2,4535 $\mathrm{mg} / 100 \mathrm{~g}$.

Keywords: beet peel, betacyanin, solvent
\end{abstract}




\section{PENDAHULUAN}

Bahan pewarna makanan bisa didapatkan dari pewarna sintetik dan pewarna alami. Dalam perkembangan industri pangan, terdapat kecenderungan menggantikan pewarna sintetik dengan pewarna alami, seperti warna merah betasianin dari bit yang telah disetujui untuk digunakan sebagai bahan tambahan makanan di Amerika Serikat (No. 1600) dan di Eropa (E-162). Di samping itu juga dibebaskan dari prosedur sertifikasi dan secara luas digunakan di belahan dunia (Castellar et al., 2003). Semakin diakuinya keberadaan pewarna alami dalam pemenuhan bahan pewarna industri pangan maka dibutuhkan eksplorasi sumber pewarna alami seperti betasianin dari beberapa tanaman dan juga dari berbagai macam bagian pada tanaman tersebut.

\section{Umbi Bit}

Bit merupakan salah satu bahan pangan yang sangat bermanfaat. Salah satu manfaatnya adalah memberikan warna alami dalam pembuatan produk pangan. Pigmen yang terdapat pada bit merah adalah betalain. Betalain merupakan golongan antioksidan. Pigmen betalain sangat jarang digunakan dalam produk pangan dibandingkan dengan antosianin dan betakaroten (Wirakusumah, 2007). Kandungan vitamin dan mineral yang ada dalam bit merah seperti vitamin $B$ dan kalsium, fosfor, nutrisi, besi merupakan nilai lebih dari penggunaan bit merah. Antioksidan merupakan substansi yang diperlukan tubuh untuk menetralisir radikal bebas dan mencegah kerusakan yang ditimbulkan oleh radikal bebas dengan melengkapi kekurangan elektron yang memiliki radikal bebas. Antioksidan akan menghambat terjadinya reaksi berantai dari pembentukan radikal bebas yang dapat menimbulkan stres oksidatif. Antioksidan banyak terdapat pada buahbuahan dan sayur-sayuran (Escribanoet al., 1998). Nilai pH untuk betalain adalah pH 4 - 6 (Stinzing dan Carle, 2007). Antioksidan dari bit merah juga mempengaruhi oleh suhu dan $\mathrm{pH}$ (Stinzing dan Carle, 2007).

\section{Betasianin}

Coultate (1996) menyatakan bahwa betalain dibagi menjadi dua kelompok yaitu betasianin dengan warna pigmen merah keunguan ( $\lambda$ max 534-555 nm) dan betaxantin dengan warna pigmen kuning ( $\lambda \max 480 \mathrm{~nm}$ ). Pada pemanasan jus pitaya, nilai ho hanya meningkat sedikit (336338). Peningkatan intensitas warna ini terjadi disertai dengan degradasi betasianin yang berkaitan dengan formasi warna kuning pada kerusakan produk (Herbach et al., 2006). Betasianin adalah zat warna yang berfungsi memberikan warna merah dan berpotensi menjadi pewarna alami untuk bahan pangan yang lebih aman bagi kesehatan dibanding pewarna sintetik. Betasianin dapat digunakan sebagai pewarna alami dalam bentuk ekstrat, akan tetapi penggunaan pelarut air dalam proses pemekatan dengan panas dapat mengakibatkan kerusakan karena titik didih air cukup tinggi $\left(100^{\circ} \mathrm{C}\right)$ sedangkan stabilitas betasianin semakin menurun pada pemanasan suhu 70 dan $80^{\circ} \mathrm{C}$ (Havlikova et al., 1983).<smiles>[R]OC[C@H]1O[C@H](Oc2cc3c(cc2C)[N+](=C/C=C2/C=C(C(=O)O)NC(C(=O)O)C2)[C@@H](C(=O)[O-])C3)[C@H](O)[C@@H](O)[C@H]1O</smiles>

Gambar 1. Struktur senyawa betasianin

Senyawa betasianin pada Gambar 1 di atas merupakan senyawa fenol yang tersubstitusi oleh gugus glikosida pada posisi orto dan mempunyai gugus kromofor. Gugus-gugus fungsional yang ada dapat berinteraksi dengan anion yang mampu menghasilkan perubahan warna. Selain itu senyawa ini memiliki kegunaan sebagai senyawa chemosensor dalam indikator asam-basa, sensor anion, sensor beberapa senyawa basa, dan reagen dalam deteksi kerusakan bahan pangan.

\section{Zat Warna Alami}

Zat warna alami (naturaldyes) adalah zat warna yang diperoleh dari alam khususnya dari tumbuh- 
tumbuhan secara langsung maupun tidak langsung. Setiap tanaman dapat sebagai sumber zat warna alam karena mengandung pigmen. Potensi ini ditentukan oleh intensitas warna yang dihasilkan dan sangat tergantung kepekaannya dalam fungsinya sebagai indikator titrasi asam basa. Beberapa contoh zat warna yang diperoleh dari tumbuh-tumbuhan dapat dilihat pada tabel 1 .

Tabel 1. Zat Warna Alami

\begin{tabular}{lll}
\multicolumn{2}{l}{ Tabel 1. Zat Warna Alami } & \\
\hline Warna & \multicolumn{1}{c}{ Sumber Utama } & Senyawa Zat Warna \\
\hline \multirow{2}{*}{ Merah } & $\begin{array}{l}\text { Kubis ungu (Brassica oleracea), ubi ungu } \\
\text { keunguan }\end{array}$ & Antomea batatas $)$, bunga rosella (Hibiscus \\
& sabdariffa), bunga sepatu (Hibiscus rosasinensis) & \\
Merah & Umbi bit Merah (Beta Vulgaris) & Betalain \\
Orange & Biji Kesumba kling(Bixa ollerana) & Biksin \\
Orange & Kayu secang(Caesalpinia sappan) & Brazilin \\
\hline
\end{tabular}

Berdasarkan tabel 1 menunjukkan bahwa tumbuhan penghasil zat warna mengandung senyawa-senyawa berwarna. Senyawa zat warna yang paling dominan penggunaanya sebagai indikator titrasi asam basa adalah antosianin karena zat tersebut paling banyak diperoleh dari bungabunga berwarna. Antosianin mempunyai sifat larut dalam air membentuk zat warna. Dalam suasana asam berwarna merah dan lebih stabil. Dalam suasana basa berwarna biru. (Siti Marwati, 2010). Selain antosianin, warna merah juga dihasilkan dari senyawa betalain yang mengandung nitrogen dan larut dalam air. Betalain terdiri dari senyawa betasantin dan betasianin. Betasantin bersifat larut dalam air membentuk larutan berwarna merah. Stabil dalam larutan panas $\left(60^{\circ} \mathrm{C}\right)$, cahaya dan udara terbuka. Senyawa tersebut lebih stabil pada kondisi pH 3,5-5,0. Pigmen betasantin berwarna kuning dan betasianin berwarna ungu. Perlu diketahui bahwa proses penggunaan zat pewarna alami dari tumbuhan harus melalui proses ekstraksi, sedangkan penelitian tentang pelarut ekstraksi masih belum banyak dilakukan terutama kaitannya dengan penggunaan jenis pelarut. Maka penelitian dilakukan untuk mencari efektifitas dari jenis pelarut dalam proses ekstraksi sehingga didapatkan kadar betalanin yang tinggi.

\section{METODE KAJIAN}

Pengekstrakan pigmen betasianin dari kulit umbi bit dilakukan dengan menggunakan ekstraksi maserasi. Variabel yang digunakan adalah pelarut tunggal dan pelarut campuran yaitu: 1) pelarut tunggal berupa Etanol; 2) pelarut campuran berupa etanol ditambah dengan asam sitrat; 3) pelarut campuran berupa etanol ditambah dengan
HCL. Lama ekstraksi adalah selama 40 menit, adapun pengujian pada sampel kulit umbi bit sebelum dilakukan ekstraksi yaitu berupa kadar abu (Sudarmaji, 1997), kadar air dengan menggunakan Ohaus MB25, kadar lemak dengan metode Soxhlet (Sudarmaji, 1997), dan kadar serat (Sudarmaji, 1997). Parameter uji yang dilakukan pada hasil ekstrasi kulit umbi bit dari 3 macam pelarut adalah kandungan betalain (Wrolstad, 2001) yang menggunakan Spektrofotometri UVVisible (UV-1240 Shimadzu) pada tiga panjang gelombang yaitu 476, 538, dan 600. Hasil absorbansi yang didapat kemudian dihitung dengan rumus dibawah ini untuk mengetahui kandungan betasianin dalam tiap macam pelarut.

$x=1,095\left(A_{538}-A_{600}\right)$

$z=A_{538}-x$

$y=A_{476}-z-\frac{x}{3,1}$

Dimana: $x=$ absorbansi betanin dikurangi pengotor

$y=$ absorbansi vulgaxantin-I

$z=$ absorbansi pengotor

konsentrasi betanin dan vulgaxantin-I ditentukan dengan persamaan sebagai berikut: 


$$
\begin{aligned}
& C_{\text {betanin }}=\frac{x}{1120} x \text { faktor pengenceran } \\
& C_{\text {vulgaxantin -1 }}=\frac{y}{750} x \text { faktor pengenceran }
\end{aligned}
$$

Kandungan pigmen betalanin adalah jumlah $\mathrm{C}_{\text {betanin }}+\mathrm{C}_{\text {vulgaxantin- } \mathrm{I}}$ dengan satuan $\mathrm{mg} / 100 \mathrm{~g}$

\section{HASIL DAN PEMBAHASAN}

Umbi bit merupakan salah satu family dari Beta vulgaris. Umbi yang dulunya hanya dimanfaatkan dari daun dan tangkainya ini memiliki warna merah pekat, terlihat merona pada bagian dalamnya. Pengolahan umbi bit sebagai pewarna alami dapat dilakukan dengan mengupas kulit umbi ini terlebih dahulu kemudian memotongnya kecil-kecil sehingga mudah untuk dihaluskan. Setelah itu, potongan kulit umbi bit ditumbuk menggunakan cawan porselin hingga halus. Setelah halus kulit umbi bit diukur kandungan air, lemak, serat, dan abu untuk mengetahui karakteristiknya. Sampel kulit umbi bit juga digunakan untuk analisis kandungan betasianin. Betasianin merupakan senyawa antioksidan yang termasuk dalam golongan senyawa fenolik. Betasianin ini banyak dimanfaatkan karena kegunaannya selain sebagai pewarna juga sebagai antioksidan dan radical savenging sebagai perlindungan terhadap gangguan akibat stres oksidatif. Pemanfaatan tanaman bit yang sering digunakan adalah pada bagian daun dan daging umbih. Faridah dkk. mengatakan bahwa betalain yang paling banyak adalah akar bit (Beta vulgaris). Akan tetapi pemanfaatan bagian akar bit masih jarang dimanfaatkan, dan setelah diambil daging umbinya, kulit umbi terbuang begitu saja. Percobaan ini dilakukan untuk mengetahui karakter dan kandungan betasianin pada kulit umbi bit.

\section{Karakteristik Kulit Umbi Bit}

Setiap jenis bahan memiliki karakteristik yang berbeda-beda, perbedaan karakteristik itu sendiri akan sangat berpengaruh terhadap penanganan dalam proses penggunaan bahan tersebut. Dalam penelitian ini penggunaan kulit umbi bit sebagai bahan yang berpotensi untuk pewarna alami memiliki karakteristik yang dapat dilihat pada tabel 2 .
Tabel 2. Karakteristik kulit umbi Bit

\begin{tabular}{lc}
\hline Komponen & Jumlah per 100 gkulit umbi \\
\hline Kadar Abu & $1,33 \mathrm{~g} \pm 0,0004$ \\
Kadar Air & $82,85 \mathrm{~g} \pm 0,0021$ \\
Kadar Lemak & $0,31 \mathrm{~g} \pm 0,0018$ \\
Kadar Serat & $5,95 \mathrm{~g} \pm 0,0032$ \\
\hline
\end{tabular}

Dari hasil pengujian karakteristik kulit bit pada tabel 2, nilai kadar abu yaitu sebesar 1,33 g dalam $100 \mathrm{~g}$ kulit umbi bit menunjukkan bahwa rendahnya kadar mineral yang terkandung dalam kulit umbi bit. Nilai berikutnya adalah kadar air dalam kulit umbi bit yaitu sebesar $82,85 \mathrm{~g}$ per $100 \mathrm{~g}$ kulit umbi bit, tinginya kadar air berpotensi mempermudah dalam proses ekstraksi. Selain itu kadar air juga dapat berpengaruh pada rendemen betasianin yang dihasilkan, karena semakin tinggi kadar air dalam kulit umbi bit maka semakin rendah kandungan senyawa fenolik disebabkan karakter dari senyawa fenolik yang memiliki kelarutan terbatas dalam air.

Nilai kadar lemak dalam sampel kulit umbi bit menunjukan nilai yang rendah juga yaitu $0,31 \mathrm{~g}$ per $100 \mathrm{~g}$ kulit umbi bit, rendahnya kadar lemak mengurangi potensi rusaknya kadar antioksidan dalam ekstrak kulit umbi bit. Hal ini disebabkan jika kita menggunakan pelarut polar dalam mengekstrak kulit umbi bit, maka ada kemungkinan lemak dalam kulit umbi bit juga dapat terlarut dan dapat meningkatkan potensi kerusakan ekstrak karena lemak mudah teroksidasi. Nilai kadar serat dalam kulit umbi bit yaitu 5,95 g per $100 \mathrm{~g}$ kulit umbi bit, nilai ini menunjukkan nilai serat yang rendah dalam kulit umbi bit. Rendahnya kandungan serat dalam kulit umbi bit menguntungkan dalam proses ekstraksi, hal ini disebabkan jika kandungan kadar serat dalam kulit umbi tinggi maka proses pengekstrakan dari kulit umbi bit akan menghasilkan rendemen yang kecil.

\section{Pengaruh Jenis Ekstrak}

Ekstraksi adalah pemisahan atau pengambilan satu komponen yang terdapat di dalam suatu bahan padat atau cairan dengan menggunakan bantuan pelarut berdasarkan perbedaan kelarutan antara pelarut dan zat terlarut. Pemisahan terjadi atas dasar kelarutan komponen-komponen dalam campuran pelarut dan zat terlarut (Hardojo, 1995). 
Efektifitas dari proses ekstraksi tidak terlepas dari kemampuan pelarut dalam melarutkan komponenkomponen zat yang terlarut. Peristiwa pelarutan suatu zat terjadi karena adanya interaksi antara pelarut dengan bahan yang dilarutkan (Effendi, 1991). Selain itu efektivitas suatu proses ekstraksi juga ditentukan oleh kemurnian pelarut, suhu ekstraksi, metode ekstraksi dan ukuran partikelpartikel bahan yang diekstraksi. Makin murni suatu pelarut dan makin lama waktu kontak antara pelarut dengan bahan yang diekstraksi pada suhu tertentu, maka ekstrak yang dihasilkan makin banyak (Geankoplis, 1991).

Penggunaan 3 jenis pelarut dalam penelitian ini yaitu terdiri dari 1 pelarut tunggal yaitu ethanol dan 2 pelarut campuran yaitu ethanol: $\mathrm{HCl}$ dan ethanol: Asam Sitrat. Fungsi ethanol dan asam sitrat untuk menurunkan $\mathrm{pH}$ pelarut. Menurut Metriva (1980) dalam Nursaerah mengatakan bahwa pengasaman pelarut menggunakan $\mathrm{HCl}$ bersifat korosif terhadap sampel. Maka perlu digunakan asam-asam organic contohnya asam sitrat dalam pengasaman pelarut. Menurut Castellar et al. (2003) bahwa betasianin memiliki tingkat kestabilan yang tinggi pada $\mathrm{pH} 5$, sedangkan menurut Reid et al. (1980) kerusakan betasianin meningkat tajam di bawah $\mathrm{pH} 4$ dan Coultate (1996) menambahkan bahwa pada nilai $\mathrm{pH}$ netral menyebabkan kerusakan betasianin dan berubah menjadi berwarna cokelat. Oleh karena itu, $\mathrm{pH}$ pelarut perlu dikondisikan pada $\mathrm{pH}$ optimal betasianin. Namun, pada penelitian ini tidak dilakukan pengukuran $\mathrm{pH}$ pada pelarut.

Betasianin merupakan pigmen berwarna merah atau merah-violet. Warna merah bit segar disebabkan oleh pigmen betasianin, suatu senyawa yang mengandung nitrogen. Bit juga mengandung betaxantin, suatu pigmen berwarna kuning. Kedua pigmen ini beragam menurut kultivar, dan dapat berubah karena kondisi lingkungan. Tingkat warna merah menunjukkan bahwa kandungan betaxantinnya sedikit, warna kuning menunjukkan bahwa tidak terdapat betasianin, dan warna putih menunjukkan tidak terdapatnya kedua pigmen tersebut.

Pada penggunaan pelarut tunggal ethanol diperoleh nilai $\mathrm{C}_{\text {betanin }}$ sebesar 0,0009 lebih kecil daripada $\mathrm{C}_{\text {betanin }}$ pada penggunaan pelarut campuran ethanol:Asam sitrat yaitu sebesar 0,0014 . Pada penggunaan pelarut campuran ethanol: $\mathrm{HCl}$ diperoleh nilai $\mathrm{C}_{\text {betanin }}$ tertinggi yaitu sebesar 0,0015. Sedangkan pada CvulgaxanthinI diperoleh nilai yang tidak berbeda antara penggunaan pelarut ethanol dan ethanol:asam sitrat yaitu sebesar 0,0007, akan tetapi pada penggunaan pelarut ethanol: $\mathrm{HCl}$ diperoleh Cvulgaxanthin-I lebih tinggi yaitu 0,0010. Kandungan betalain pada kulit umbi bit yang diperoleh dari penggunaan pelarut ethanol diperoleh 1,6084 mg/100g, pelarut ethanol:Asam sitrat $2,1384 \mathrm{mg} / 100 \mathrm{~g}$, dan pelarut ethanol: $\mathrm{HCl}$ sebesar 2,4535 mg/100g sampel kulit umbi bit.Suhu yang digunakan pada ketiga perlakuan pelarut ini dianggap tidak berpengaruh karena suhu ekstraksi dilakukan pada suhu ruang. Begitu juga dengan waktu ekstraksi pada ketiga perlakuan pelarut sama yaitu 40 menit.

Tabel 3. Kandungan Betasianin pada kulit umbi bit

\begin{tabular}{lccc}
\hline Pelarut & Cbetanin & Culgaxanthin-I & $\begin{array}{c}\text { Betalain } \\
(\mathbf{m g} / \mathbf{1 0 0 g})\end{array}$ \\
\hline Ethanol & 0,9276 & 0,6808 & 1.6084 \\
Ethanol +As. Sitrat & 1,4060 & 0,7324 & 2.1384 \\
Ethanol + HCL & 1,4757 & 0,9778 & 2.4535 \\
\hline
\end{tabular}

Berdasarkan hasil penelitian dapat dilihat bahwa perlakuan pelarut yang paling baik dalam ekstraksi betasianin pada kulit umbi bit yaitu penggunaan pelarut ethanol: $\mathrm{HCl}$. Hal ini diduga karena kombinasi pelarut ethanol: $\mathrm{HCl}$ memberikan tingkat kepolaran yang mendekati tingkat kepolaran betasianin pada kulit umbi bit sehingga meningkatkan kemampuan untuk melarutkan betasianin dan ekstraksi dapat terjadi secara maksimal. Vogel (1987) menyatakan bahwa daya melarutkan yang tinggi ini berhubungan dengan kepolaran pelarut dan kepolaran senyawa yang diekstraksi.

\section{KESIMPULAN}

Dari hasil penelitian ini dapat ditarik kesimpulan bahwa pada kulit umbi bit memiliki kandungan air yang tinggi yaitu 82,85 persen, kadar lemak, serat, dan abu yang rendah yaitu 0,31 persen, 5,95 persen, dan 1,33 persen. Oleh karena 
rendahnya kandungan air, lemak, serat, dan abu tersebut, proses ekstraksi kulit umbi bit tidak terlalu sulit. Hal ini juga ditunjukkan dengan kandungan air yang tinggi dengan kandungan serat yang rendah. Analisis kandungan betasianin antara tiga pelarut maksimal pada pelarut ethanol: $\mathrm{HCl}$ dengan nilai sebesar $2,4535 \mathrm{mg} / 100 \mathrm{~g}$.

\section{DAFTAR PUSTAKA}

Castellar, R., Obon, J.M., Alacid,M., Lopes, J.A.F. 2003. Color properties and stability of betacyanin from Opuntia fruits. J. Agric. Food Chem. 51: 2772-2776.

Coultate, T.P. 1996. Food The Chemistry of Its Components. 3rd edition. The Royal Society and Chemistry Company. Cambridge.

Effendi, W. 1991. Ekstraksi, Purifikasi dan Karakterisasi Antosianin dari Kulit Manggis (Garcinia mangostana L.). Fakultas Teknologi Pertanian. Institut Pertanian Bogor. Bogor.

Escribano, J., Pedreno, M.A., Garcia-Carmona, F., Munoz, R. 1998. Characterization of the antiradical activity of betalains from Beta vulgaris L. Roots. Phytochem. Anal. 9:124-127.

Geankoplis C.J. 1991. Transport Processess and Unit Operations, 2nd Ed, Allyn and Bacon, Inc, Toronto.

Hardojo, L. 1995. Teknologi Kimia Bagian II. Cetakan Pertama, Penerbit PT. Prandnya Paramita, Jakarta.

Havlikova, L.K., Mikova, K. 1983. Heat Stability of Betacyanins. Lebensm Unters Forsch 177: $247-250$

Herbach, K.M., Stinizing, F.C., Carle, R. 2006. Betalain stability and degradation structural and chromatic aspects. J. Sci. of food. Vol. 71.Nr.4.
Jackman, R.L., Smith, J.L. 1996. Anthocyanins and Betalains in Natural Food Colorants. Blackie Academic and Professional. London.

Marwati, S. 2010. Aplikasi Beberapa Bunga Berwarna sebagai Indikator Alami Titrasi Asam Basa. Prosiding Seminar Nasional Penelitian. Pendidikan dan Penerapan MIPA FMIPA UNY

Metriva, M. 1995. Mempelajari Ekstraksi Antosianin dari Kulit Buah Manggis (Garnicia mangostana L) Menggunakan Pelarut Metanol yang Diasamkan. (Skripsi) Fakultas Teknologi Pertanian. Institut Pertanian Bogor. Bogor.

Reid, M., Jack, S., Paul, L., Young, R.E. 1980. Effects of $\mathrm{pH}$ and ethephon on betacyanin leakage from beet root discs. Plant Physiol 66: 1015-1016.

Stintzing, F.C., Carle, R. 2007. Betalainsemerging prospects for food scientists. Tends Food Sci. Technol. 18: 514 - 525.

Sudarmadji, S.B., Haryono, S. 1997. Prosedur Analisa untuk Bahan Makanan dan Pertanian. Yogyakarta: Penerbit Liberty

Vogel, A.C. 1987. Textbook of Practical Organic Chemistry. Fourth Edition. Pp.130-136.

Wirakusumah, E. 2007. Cantik Awet Muda Dengan Buah Sayur dan Herbal. Jakarta: Penebar Swadaya.

Wrolstad, R.E., Giusti, M.M. 2001. Unit F1.2: anthocyanins. Characterization and measurement with $U V$-visible spectroscopy. In: Wrolstad, RE, editor. Current protocols in food analytical chemistry. New York: John Wiley \& Sons. p. F1.2.1- 1.2.13. 